\title{
RESTRICTIVE COVENANTS: WHEN THE HONEYMOON ENDS
}

\author{
SHAFIK BHALLOO AND ALISHA PARMAR*
}

\begin{abstract}
The law governing restrictive covenants in employment agreements has evolved rapidly in recent years and continues to do so. This article provides an in-depth examination of the function of restrictive covenants in the employment context through an evaluation of jurisprudence. The article analyzes various aspects of restrictive covenants, including their enforceability, relationship with the doctrine of severance, interpretation through the functionalist and formalist approaches, and effects on pre-existing employment agreements and wrongful termination. The author concludes by providing recommendations for drafting and implementing restrictive covenants.
\end{abstract}

\section{TABLE OF CONTENTS}

I. INTRODUCTION . . . . . . . . . . . . . . . . . . . . . . 643

II. The ENFORCEABILITY of Restrictive COVENANTS . . . . . . . . . . . 644

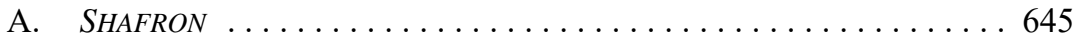

B. Clear, Certain, and not Vague . . . . . . . . . . . . 646

C. Protect a Legitimate Proprietary Interest . . . . . . . . . . . 647

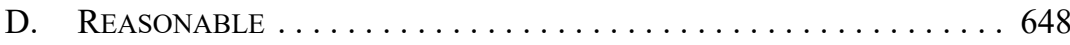

E. REASONABle In TERMS OF THE PUblic InTEREST . . . . . . . . . 650

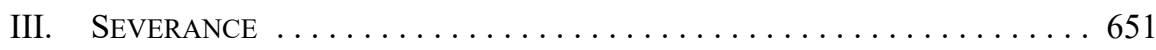

A. Notional SEverance And "Blue-Pencil" SEverance . . . . . . 651

B. Descending Scope Clauses or "Waterfall” Clauses . . . . . 654

IV. THE FUNCTIONALIST APPROACH

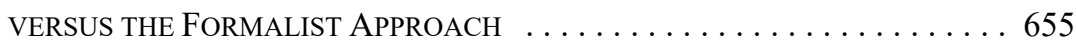

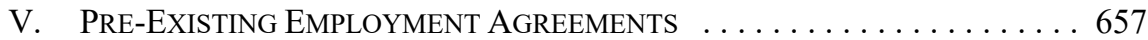

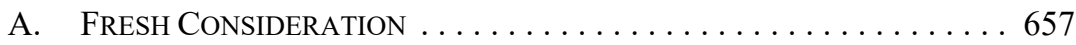

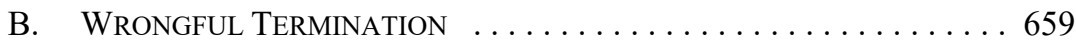

VI. RECOMMENDATIONS ........................ 660

\section{INTRODUCTION}

Anticipating post-employment issues when an employment agreement has just been entered into might seem counterintuitive, but that is exactly the function of restrictive covenants. This strange sentiment is more relatable when an analogy to marriage is drawn. How many passionate couples tie the knot, only to later bitterly regret not entering a prenuptial agreement?

Like prenuptial agreements, restrictive covenants are designed to lessen the blow when the love dies. They are terms in the employment agreement intended to minimize the harm a former employee can cause an employer when the employment relationship is terminated.

Shafik Bhalloo is a partner of Kornfeld LLP, a corporate-commercial law firm in Vancouver, British Columbia. He also has an appointment as a Professor of Practice at the Beedie School of Business at Simon Fraser University and serves as a Member on the Employment Standards Tribunal of British Columbia. Alisha Parmar is an associate with Kornfeld LLP with a preferred area of practice in corporate and commercial law. 
This article provides an overview of the law governing restrictive covenants in the employment context.

Part II examines the enforceability of restrictive covenants generally and introduces nonsolicitation and non-competition clauses. Part III delves into the doctrine of severance and its application to restrictive covenants. Part IV considers the distinction between the functionalist and formalist approaches to restrictive covenants. Part V reviews restrictive covenants within pre-existing employment relationships and the effect of wrongful termination. Finally, Part VI concludes with recommendations for drafting and implementing restrictive covenants.

\section{The ENForceabiLity OF RESTRICTIVE COVENANTS}

Generally speaking, restrictive covenants place restrictions on the post-employment conduct of a former employee in an effort to protect the business of the employer.

There are two main types of restrictive covenants: non-competition clauses and nonsolicitation clauses. A non-competition clause restricts the ability of a former employee to partake in business that competes with that of the former employer, whereas a nonsolicitation clause prevents the employee from soliciting customers or clients of the former employer. Thus, in a given employment relationship, a non-competition clause will necessarily be more restrictive than a non-solicitation clause, since it prevents the former employee from engaging in that type of business entirely, albeit for a specified period.

It has long been recognized by Canadian courts that this post-employment influence presents a clash of interests. As expressed by the Supreme Court of Canada in Shafron $v$. KRG Insurance Brokers (Western) Inc., " [r]estrictive covenants give rise to a tension in the common law between the concept of freedom to contract and public policy considerations

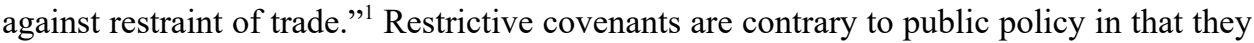
interfere with the ability of former employees to ply their trade freely. ${ }^{2}$

Further, restrictive covenants in the employment context are scrutinized much more rigorously than in the sale of a business. A restrictive covenant in the context of the sale of a business normally precludes the vendor from competing with the purchaser of that business. ${ }^{3}$ However, the Supreme Court of Canada has noted that, unlike the situation of an employee, the vendor of a business likely has more bargaining power and is being compensated for the sale of goodwill, so the restrictive covenant is easier to justify. ${ }^{4}$ In contrast, employees normally lack the bargaining power that a purchaser of a business has when it comes to negotiating the terms of a contract. ${ }^{5}$

2009 SCC 6, [2009] 1 SCR 157 at para 16 [Shafron].

Ibid.

Ibid at para 15 .

Ibid at paras 18-23.

Valley First Financial Services Ltd v Trach, 2004 BCCA 312, 30 BCLR (4th) 73 at para 44 [Valley First]; Rhebergen v Creston Veterinary Clinic Ltd, 2014 BCCA 97, 372 DLR (4th) 191 at para 55 [Rhebergen]; Payette v Guay Inc, 2013 SCC 45, [2013] 3 SCR 95 at para 45 [Payette]. 
Despite these factors weighing against the acceptance of both classes of restrictive covenants, the clauses have not been declared unenforceable outright by Canadian courts. Even in the employment context, restrictive covenants are only unenforceable prima facie. In order to give meaning to the principle of contractual freedom, the courts will uphold those restrictive covenants that meet the standard of reasonableness. To be found reasonable, a restrictive covenant in the employment context must meet all of the following criteria:

1. protect a legitimate proprietary interest of the employer;

2. be reasonable in terms of:
a. temporal length;
b. spatial area covered;
c. nature of the activities prohibited; and
d. overall fairness;

3. have clear, certain and not vague terms; and

4. be reasonable in terms of the public interest. ${ }^{6}$

The onus to meet the first three criteria is on the party seeking to uphold the restrictive covenant, while the onus switches to the party seeking to strike the clause for the last criterion. $^{7}$

\section{A. SHAFRON}

Before delving into the criteria for finding a restrictive covenant enforceable, it is helpful to briefly review the facts of the Shafron decision. ${ }^{8}$ Although it is not an especially recent decision, it is worthy of note as the Supreme Court of Canada considered the enforceability of and policy behind restrictive covenants in detail.

In Shafron, the plaintiff sold his shares in his insurance agency business to KRG. KRG then renamed the business as KRG Insurance Brokers (Western) Inc. (the defendant). The plaintiff worked for the defendant after the sale of shares took place. Over a period of 12 years, the plaintiff and defendant entered into several employment agreements. The relevant employment agreements included a non-competition clause. The clause restricted the plaintiff from being employed in the business of an insurance brokerage within the "Metropolitan City of Vancouver" for a period of three years after leaving his employment for any reason other than termination without cause. Just prior to the expiry of the last employment agreement, the plaintiff left his employment with the defendant and commenced work as an insurance salesman for another agency. 
The defendant commenced an action against the plaintiff. The trial judge dismissed the action finding, inter alia, that "Metropolitan City of Vancouver" was not clear, certain or reasonable. The Court of Appeal reversed this decision by applying the doctrine of notional severance (discussed in Part III). ${ }^{9}$

The Supreme Court of Canada overturned the Court of Appeal's decision. In the process, it conducted an extensive review of the case law surrounding restrictive covenants and how it has progressed over the years. Although the decision is interesting for many reasons, one initial point is that the Court treated the sale of shares to the defendant as being separate from the subsequent employment agreements entered into between the parties. ${ }^{10}$ Since the employment agreement and the sale of shares were not part of one and the same document, the non-competition clause was viewed as a restrictive covenant in the context of an employment agreement and not the sale of a business. ${ }^{11}$ As discussed above, restrictive covenants in the sale of a business are subject to less scrutiny because of the allegedly greater equality of bargaining power. It is arguable that the outcome for the defendant would have been different had the non-competition clause been included as part of the transaction that dealt with the original disposition of shares.

\section{B. Clear, Certain, And Not Vague}

Although it is the third criterion listed in the test above, the Supreme Court of Canada in Shafron stated that a determination of reasonableness cannot be made without first establishing the meaning of the restrictive covenant. ${ }^{12}$ An ambiguous restrictive covenant is prima facie unenforceable because the party seeking to uphold it will not be able to demonstrate it is reasonable in light of the ambiguity. ${ }^{13}$ Ambiguity may be found with respect to the scope of the activity, time, or geographical area of the restrictive covenant. Any of which may effectively pose an obstacle against having a restrictive covenant upheld. ${ }^{14}$

It is noteworthy that the interpretation of restrictive covenants to resolve ambiguity reflects the courts' general dislike of such clauses. Unlike restrictive covenants in commercial agreements, where the courts will interpret ambiguities to fairly give effect to the parties' intentions, in the employment context the courts show reservation in employing their own notions of reasonableness and what the parties' intentions may have been to resolve such ambiguities. ${ }^{15}$ As expressed by Justice Lowry in Rhebergen, in the realm of restrictive covenants " $[\mathrm{t}]$ here is no place for an ambiguity the resolution of which is not readily apparent." 16 However, where the restrictive covenant can be construed through the plain and ordinary meaning of its words and the ordinary rules of grammar, then the clause will not be found ambiguous. ${ }^{17}$

Ibid at paras $10-12$.

Ibid at paras $21-25$.

Ibid at paras 15-25.

Ibid at para 27.

Ibid at paras 27,43 .

Ibid at para 43; Payette, supra note 5 at para 2.

Shafron, ibid at para 47.

Rhebergen, supra note 5 at para 55.

Ibid at para 74 . 
In Jacobs v. PHAT Training Inc., the Alberta Court of Queen's Bench recently considered the following non-solicitation clause, in the context of an employee who was a personal trainer:

In the event of termination, the parties acknowledge and agree that all clients of the Consultant that were provided by P.H.A.T. Training Inc., shall become property of P.H.A.T. Training Inc. and the Consultant shall no longer train or otherwise be associated with such clients without prior written consent of P.H.A.T. Training Inc. or at the expiration of one (1) year from the date of termination. ${ }^{18}$

In considering the non-solicitation clause, the court noted the phrase "otherwise be associated with" was "at best ambiguous and at worst overbroad and unreasonable." Court acknowledged that the parties clearly intended the phrase to modify "training," but it was not clear how it was to be modified. As a result, the Court could not precisely determine what kinds of services were intended to fall under "otherwise be associated with," and the clause was ambiguous and unenforceable. ${ }^{20}$

\section{Protect a Legitimate Proprietary Interest}

The restrictive covenant must also protect a legitimate business interest of the employer. The employee might acknowledge that the restrictive covenant does this and is reasonable in a boiler-plate clause inserted in the employment contract, but that may not be the case. Just because it is acknowledged that a restrictive covenant is reasonable does not make it so, and it does not increase the likelihood that it will be upheld. At times, restrictive covenants may be drafted overly broad in scope and overreach the legitimate proprietary interest of the employer - such clauses will be struck down.

This, in part, explains the well-established practice of Canadian courts to strike noncompetition clauses where a non-solicitation clause would sufficiently protect the employer's interests. ${ }^{21}$ As compared to non-solicitation clauses, non-competition clauses present a broader restriction of the employee's post-employment conduct. It has long been held that, in the absence of special circumstances, the former employer will not have a proprietary interest entitling him to protection from the competition of the former employee. ${ }^{22}$ As stated by the Ontario Court of Appeal in H.L. Staebler Company Ltd. v. Allan, it is "clear that a non-solicitation clause is normally sufficient to protect an employer's proprietary interest and that a non-competition clause is warranted only in exceptional circumstances." 23

Trade secrets, customer lists, and other confidential information obtained during the course of employment have all been recognized as proprietary interests worthy of protection by restrictive covenants. ${ }^{24}$ "Trade connections" or "trade attachments" have also been viewed as legitimate proprietary interests provided the employer is able to show "tangible evidence

2014 ABQB 100, 23 BLR (5th) 176 at para 8.

Ibid at para 157.

Ibid at para 158 .

Valley First, supra note 5 at para 49.

Winnipeg Livestock Sales Ltd v Plewman, 2000 MBCA 60, 192 DLR (4th) 525 at para 27.

2008 ONCA 576, 92 OR (3d) 107 at para 40 [HL Staebler].

Fonkalsrud v Boxall, 2014 SKQB 134, 444 Sask R 291 at para 27 [Boxall]. 
of customer loyalty to the business. ${ }^{, 25}$ In Boxall, the Court acknowledged that although no claim could be made for a proprietary interest in future or potential clients per se, the respondent had shown a proprietary interest in "maintaining her own client base and the trade connections and referral system she had nurtured over the years. ${ }^{26}$ However, even if the trade connections or attachments are developed by the employer, this does not entail they can be protected by a restrictive covenant, especially if the employee independently developed these connections or attachments.

In Avidworx Productions Ltd. v. Culbertson, the British Columbia Supreme Court recently considered proprietary interest in the case of a very experienced employee. ${ }^{27}$ In that case, the employer ran a niche business "providing displays, business advice, and support to retailers who provide after-market audio related equipment and services such as car audio equipment." 28 The employer argued that it invested heavily in the design and building of displays, and in fact, that it was intellectual property protected by copyright. Thus, the employer required employees to agree to non-compete and non-solicitation provisions at the commencement of employment. The employee in question had agreed to a non-compete clause stating that he would not, for a period of 18 months following the term of the contract, engage in any business in Canada or the United States which was substantially the same as or competed with the business of the employer by utilizing methodologies and business processes developed by the employer. The employee had further agreed to not solicit any customers "of the" employer for a period of two years following employment. The employment relationship ended and the employee continued to work in the same field. The employer sought an injunction to enjoin the employee from soliciting its customers and using any of the purportedly confidential information. ${ }^{29}$

One of the issues with obtaining the injunction application was that the restrictive covenants could not restrict what the employee was doing. ${ }^{30}$ The employee had significant prior experience in the car audio and electronic sales industry, meaning that he already had the requisite skills to be in business before he was employed by the employer. Thus, he was not using any methodologies or business processes developed by the employer, as specified by the non-competition clause. Further, he had a wide range of contacts prior to being hired and the customers he had allegedly solicited were individuals that he had known previous to his employment with the employer. As a result, it appeared that neither of the restrictive covenants was applicable to the scenario and the injunction requested by the employer was denied. ${ }^{31}$

\section{REASONABle}

Reasonableness is the "mechanism by which a court decides whether a covenant is "overly broad' or is only that which is reasonably required for the employer's protection." 32 This is

Ibid at para 28 .

Ibid at para 31 .

2015 BCSC 135 (CanLII).

Ibid at para 2 .

Ibid at paras $1-8$.

Ibid at para 101 .

Ibid at paras 105-107.

HL Staebler, supra note 23 at para 36 
done by considering the extent of the activity prohibited by the restrictive covenant and the temporal and spatial scope of the prohibition, in light of the proprietary interests to be protected. ${ }^{33}$ Despite showing that there was a proprietary interest in her own client lists, the plaintiff in Boxall did not ultimately succeed because of the third criterion, reasonableness. ${ }^{34}$

An assessment of reasonableness also takes into consideration the factual context of the restrictive covenant including, inter alia, the employment agreement, the nature of the employer's business, and the former employee's position within that business. ${ }^{35}$ A properly circumscribed restrictive covenant offers protection of the employer's interest without unduly inhibiting the post-employment conduct of the former employee. ${ }^{36}$ As a result, a restrictive covenant may be upheld depending on the factual context where it otherwise would not.

In Boxall, the defendant was a massage therapist who had entered into an agreement to provide massage therapy services at the plaintiff's clinic. ${ }^{37}$ Their relationship was described as being of sole proprietor (plaintiff) and independent contractor (defendant). The agreement stated that the defendant would not work or provide services of any kind similar to those provided at the massage therapy clinic within a one kilometer radius of the massage therapy clinic and for a period of two years following termination of the agreement. When the agreement was terminated, the defendant set up her own massage therapy business within a one kilometer radius of the massage therapy clinic. The plaintiff alleged that her business suffered as a result and was successful at trial. ${ }^{38}$

The defendant was successful on the appeal. ${ }^{39}$ This was despite the Court acknowledging the legitimate proprietary interest the plaintiff had in her client base and despite further acknowledging that, as a non-traditional work relationship where there was arguably less inequality of bargaining power, the non-competition clause should be subject to less scrutiny. The clause was unreasonable because the plaintiff could have sufficiently protected her interests through a non-solicitation clause. Instead, the non-compete clause prevented the defendant from treating clients she had gained herself in the one kilometer radius. As a result, the decision of the lower court was set aside. ${ }^{40}$

Similarly in Evans v. Sports Corp., a non-solicitation clause was held to be unreasonable where it extended to past clients of the employee. ${ }^{41}$ In that case, the employee was employed by an agency to represent hockey players. When the employee left the employer he brought an action for unpaid wages, and the employer counterclaimed that he was in breach of his non-solicitation agreement. The clause in question provided:

$[\mathrm{H}] \mathrm{e}$ will not, either during the continuance of his employment or for a period of 24 months thereafter, directly or indirectly through others, call on, solicit, divert or take away or attempts to call on, solicit, divert or take away any client of the Company which has been a client of the Company or any other company to

Shafron, supra note 1 at para 43.

Boxall, supra note 24.

HL Staebler, supra note 23 at paras 36, 47.

Ibid at para 42 .

Boxall, supra note 24 at para 2.

Ibid at paras $1-8$.

Ibid at paras 56-57.

Ibid.

2013 ABCA 14, 358 DLR (4th) 428. 
whom Evans provided any services related to the Company's business. This provision shall not apply to those clients of the Company from whom Evans has received or is owed payments under section 4 of this agreement. $^{42}$

Not only was this clause ambiguous, the Court further commented that it was unreasonable:

\begin{abstract}
In this case, the non-solicitation clause in 7(c) is directed at "any client of the Company which has been a client of the Company or any other company to whom Evans provided any services related to the Company's business". It seems likely that this provision is aimed at prohibiting solicitation of other people previously given services by Evans while they were clients of this or a related company. However, the clause can also be read as prohibiting solicitation of past clients of TSC. It is difficult to understand why it would be reasonable to restrain Evans from soliciting past clients which have already left the company. ${ }^{43}$
\end{abstract}

As a result, the restrictive covenant was found to be unenforceable.

In Anderson v. Berry-Heldt, the British Columbia Court of Appeal upheld a noncompetition clause which prevented a travel agent from competing with her former firm for one year in British Columbia, Alberta, Saskatchewan, Manitoba, and Ontario. ${ }^{44}$ The Court of Appeal affirmed the trial judge's ruling on the basis that the travel agency had shown sufficient business was conducted in the five provinces and that the non-competition clause was agreed to in contemplation of a sale of shares of the travel agency.

In contrast to Anderson, the Ontario Court of Appeal in Mason v. Chem-Trend Limited Partnership struck down a restrictive covenant which prohibited the former employee of an international company from dealing with any businesses that may have been a customer of the employer during the time he was employed. The Court found that the fact an employee had worked for the employer for 17 years made the restriction on dealing with possible former customers unworkable and therefore unreasonable. ${ }^{45}$ One reason for this finding was that the restriction was not limited to customers that the former employee had dealt with personally, but applied to all customers of the employer, which the employee would have no way of identifying. This ambiguity meant that the employee would effectively be unable to compete with the former employer, lest he engage a past customer.

\title{
E. Reasonable in terms of The Public Interest
}

Even if a restrictive covenant manages to overcome the first three criteria of the test for reasonableness, the party seeking to strike the clause may still show that it is unenforceable on the last criterion. Whether or not the restrictive covenant is reasonable in terms of the public interest largely involves an assessment of whether the clause unduly restricts competition. The Supreme Court of Canada's remarks in JG Collins Insurance Agencies Ltd. $v$. Elsley are instructive in this regard: 
After the party relying on a restrictive covenant has established its reasonableness as between the parties, the onus of proving that it is contrary to the public interest lies on the party attacking it. Since in my opinion the respondent has established what is required of him, the matter of the public interest must now be considered.

Unless it can be said that any and every restraint upon competition is bad, I do not think that the enforcement of the clause could be considered inimical to the public interest. There were twenty to twenty-two general agents in Niagara Falls according to the evidence as of the date of trial, employing eighty to ninety employees. There was nothing to suggest that the people of Niagara Falls would suffer through the loss, for a limited period, of the services of Elsley in the general insurance business. ${ }^{46}$

Similarly, in Reed Stenhouse Companies Ltd. v. Learning, the Court held that a restrictive covenant was enforceable and not contrary to the public interest where "[t]he evidence further shows that there is at least one other agent or broker in the area competing with the plaintiff, being the company which now employs Mr. Learning. While the elimination of competition in the marketplace may be properly considered in assessing this element, I conclude that the public interest is not adversely affected here." 47

In Reed Stenhouse, the clause in question was a non-solicitation clause which restricted the former employee, an insurance broker, from soliciting the plaintiff employer's clients for one year following employment.

\section{SEVERANCE}

\section{A. Notional SeVErance AND "Blue-PenCIL" SEVERANCE}

Unless a restrictive covenant manages to meet all the criteria delineated above, it will be unreasonable. Despite the finding of unreasonableness, the doctrine of severance may be able to assist in upholding parts of the clause so that the restrictive covenant is not struck completely. However, Canadian courts have emphasized that severance cannot be relied upon to modify an unenforceable restrictive covenant in the employment context. ${ }^{48}$

Severance is the process by which a court upholds part of a contractual provision, which would otherwise be unenforceable, by modifying the terms of the provision. There are two main forms of severance: notional severance and "blue-pencil" severance. As stated by the Supreme Court of Canada in Transport North American Express Inc. v. New Solutions Financial Corp., "[t]he blue-pencil approach as a technique of effecting severance involves the actual excision of the provisions leading to the illegality, leaving those promises untainted by the illegality to be enforced." ${ }^{49}$ Therefore, blue-pencilling only involves removing words from the illegal provision and not adding or changing the words of the clause. In contrast, notional severance permits the court to alter the language of the agreement. It consists of "reading down an illegal provision in a contract that would be unenforceable in order to make it legal and enforceable.",50 
In Transport North American, the Supreme Court of Canada unequivocally broadened the ability of Canadian courts to cure illegal contractual provisions. In that case, the Court considered a contractual provision that offended section 347 of the Criminal Code, which sets the criminal rate of interest at 60 percent. ${ }^{51}$ As background, in calculating whether the interest rate is greater than 60 percent, a court will consider various different types of payments made under a contract. Generally speaking, a contract will be caught by section 347 if the payments under a contract taken together result in a greater than 60 percent return.

In Transport North American, there were various payments made under the contract caught by section 347, which resulted in the interest rate under the contract effectively being greater than 60 percent. ${ }^{52}$ Since the effective rate of interest was made up of various different payments, blue-pencilling would have had the effect of significantly lowering the rate agreed upon by the parties; it would necessarily involve "striking-out" an entire obligation to pay under the contract.

Instead, the Court used notional severance to set the interest rate under the contract at 60 percent. ${ }^{53}$ The Court noted that blue-pencilling can fundamentally alter the contract agreed to by the parties and does not necessarily do justice to the intention of the parties. ${ }^{54}$ In explicitly adopting the doctrine of notional severance, the Court seemed intent to remove the "common law constraints imposed on courts unaided by principles of equity." 55

In Shafron, the Supreme Court of Canada considered an appeal wherein the British Columbia Court of Appeal utilized the doctrine of notional severance to cure an unenforceable restrictive covenant in an employment agreement. ${ }^{56}$ As mentioned previously, the restrictive covenant used the words "Metropolitan City of Vancouver" to circumscribe the geographical area in which the former employee was not permitted to carry on business. The words were found by the trial judge as being ambiguous under the test for reasonableness, so that the restrictive covenant was initially held unenforceable. ${ }^{57}$ The Court of Appeal overturned the decision, finding that the doctrine of notional severance could be used to conclude that "Metropolitan City of Vancouver" referred to the "City of Vancouver, the University of British Columbia Endowment Lands, Richmond, and Burnaby." 58

The Supreme Court of Canada reversed the Court of Appeal's finding. In a unanimous decision, the Court held that "notional severance has no place in the construction of restrictive covenants in employment contracts." ${ }^{59}$ Permitting notional severance in the context of employment agreements would only encourage employers to draft overly-broad restrictive covenants in the hope that courts would then sever the illegal provisions. ${ }^{60}$ The Court further stated that, unlike Transport North American, there is no bright line test to

Criminal Code, RSC 1985, c C-46, s 347.

Supra note 49 at para 16.

Ibid.

Ibid at para 28-30.

Ibid at para 29.

Shafron, supra note 1 at paras 46-50.

Ibid at para 10 .

KRG Insurance Brokers (Western) Inc v Shafron, 2007 BCCA 79, 25 BLR (4th) 193 at para 61.

Shafron, supra note 1 at para 37.

Ibid at para 33 . 
distinguish what is illegal and what is not when a court is making an assessment of reasonableness. The Court explained as follows:

In the case of an unreasonable restrictive covenant, while the parties may not have had the common intention that the covenant be unreasonable, there is no objective bright-line rule that can be applied in all cases to render the covenant reasonable. Applying notional severance in these circumstances simply amounts to the court rewriting the covenant in a manner that it subjectively considers reasonable in each individual case. Such an approach creates uncertainty as to what may be found to be reasonable in any specific case. ${ }^{61}$

Unlike the illegal interest rate, which is specified in legislation, the point at which a restrictive covenant is reasonable or, in other words "not illegal," is not clearly set out. By applying notional severance, the Supreme Court of Canada found that the Court of Appeal was erroneously applying its own notions of reasonableness to make the contract enforceable. $^{62}$

Even more, the Court held that blue-pencil severance can only be applied sparingly to restrictive covenants in the employment context. The Court stated that blue-pencil severance can only be resorted to in rare cases:

I am of the opinion that blue-pencil severance may be resorted to sparingly and only in cases where the part being removed is clearly severable, trivial and not part of the main purport of the restrictive covenant. However, the general rule must be that a restrictive covenant in an employment contract found to be ambiguous or unreasonable in its terms will be void and unenforceable. ${ }^{63}$

The Court in Shafron also briefly considered whether the doctrine of rectification could be applied to correct the restrictive covenant. The defendant argued that it was "obvious" there had been a mistake in the language of the covenant, and that "Metropolitan City of Vancouver" is a mistaken description. ${ }^{64}$ However, the doctrine of rectification is utilized to amend contracts where the parties have agreed on a particular matter but the parties' intentions are not properly reflected by the contract. The Court refused to apply the doctrine of rectification, stating as follows:

In Performance Industries Ltd. v. Sylvan Lake Golf \& Tennis Club Ltd., 2002 SCC 19, [2002] 1 S.C.R. 678 (S.C.C.), Binnie J., at paras. 37-40, set out the necessary requirements for rectification: (1) the existence and content of the inconsistent prior oral agreement; (2) that the party seeking to uphold the terms of the written agreement knew or ought to have known about the lack of correspondence between the written document and the oral agreement, in circumstances amounting to fraud or the equivalent of fraud; and (3) "the precise form" in which the written instrument can be made to express the prior intention.

In this case, KRG Western has shown no prior oral agreement, let alone the content of one. Rather, it simply asserts that "something must have gone wrong with the language" of the contract. Without pointing to a 
prior agreement that was departed from when the contract was put into writing, rectification is not available. $^{65}$

With no prior agreement, there was no indication in these circumstances that the parties had agreed on something other than "Metropolitan City of Vancouver." 66

Although the decision in Shafron was made in the context of a non-competition clause, the principles apply to all restrictive covenants in employment agreements. For example, the British Columbia Supreme Court recently confirmed in Jones that the principles enunciated apply equally to non-solicitation clauses. ${ }^{67}$

In Jones, the defendant was employed as a financial advisor by the plaintiff. The plaintiff was a national investment dealer. The employment agreement entered into by the plaintiff included a non-solicitation clause. ${ }^{68}$ The clause consisted of two different sentences. The first sentence specified that the defendant would not, for a period of one year, solicit any customer of the plaintiff that the defendant served or who became known to the defendant in the course of her employment. However, the second sentence restricted the defendant's interactions with "any" customer of the plaintiff. Notably, the second sentence began with the wording "[y]our agreement not to solicit means." ${ }^{69}$ The defendant sought a summary determination as to whether the non-solicitation clause was reasonable. ${ }^{70}$

In its decision, the Court considered whether severance could be used to make the nonsolicitation clause reasonable. ${ }^{71}$ Specifically, the Court considered blue-pencil severance, since it could potentially be used to strike out the broader second sentence of the nonsolicitation clause, leaving the more reasonable first sentence behind. However, the Court held that the very language of the second sentence claimed to explain the first sentence, and therefore it could not be viewed as severable, trivial or separate from the main purport of the non-solicitation clause. ${ }^{72}$ Thus, blue-pencil severance would not be applicable.

\section{B. Descending Scope Clauses OR "Waterfall" Clauses}

Descending scope clauses or "waterfall" clauses are multi-tiered clauses which arrange the clause in a manner that encourages blue-penciling by courts. For example, a noncompetition clause may prohibit the former employee from engaging in a competing business in: (1) Canada (2) the Province of British Columbia; (3) the City of Vancouver. By including varying degrees of breadth, waterfall clauses are designed to permit the courts to strike out clauses that are unreasonable while leaving the employer with some measure of protection through the portion of the clause left standing.

Ibid at paras 53-54.

Ibid at para 57.

Supra note 48 at para 19.

Ibid at paras 4-5.

Ibid at para 4.

Ibid at para 10 .

Ibid at paras $12-17$.

Ibid at paras 23-25. 
Prior to Shafron, Canadian courts had ruled that waterfall clauses were not too ambiguous to be upheld. In Community Credit Union Ltd. v. Ast, the non-competition clause in question utilized the waterfall technique by specifying a series of length, time, and geographic area that the non-competition clause would apply to. ${ }^{73}$ The Court relied on several earlier cases that suggested each provision of the restrictive covenant was a separate and distinct covenant and therefore severable from all others. ${ }^{74}$

However, the strong statement made by the Supreme Court of Canada in Shafron against blue-pencil severance has cast aspersions on the use of waterfall clauses in restrictive covenants. In Bonazza v. Forensic Investigations Canada Inc., the Ontario Superior Court of Justice reversed an arbitrator's decision which partially relied on the Community Credit decision. The Court found that a restrictive covenant including a waterfall provision for geographic scope, similar to the one upheld in Community Credit, was "by its very nature ambiguous." 75 The Court pronounced emphatically that "Shafron sounds the death knell for descending scope restrictive covenants." 76

\section{The FunCtionalist APPROACH VERSUS THE FORMALIST APPROACH}

It is notable that a clause in an employment agreement will only attract the reasonableness test delineated above if it is in restraint of trade. To clarify, clauses in employment agreements may be drafted in a manner that effectively control the post-employment conduct of an employee without directly imposing any restrictions. These more nuanced clauses place a burden on the employee for engaging in specific conduct rather than directly prohibiting the former employee from certain conduct. Then, whether or not the reasonableness test applies depends on whether the court assessing the clause views it as a restraint of trade, or rather, whether the court has adopted the functionalist or formalist approach for evaluating restrictive covenants.

The formalist approach requires a clause to be structured as a prohibition in order to constitute a restraint of trade. Under this view, clauses that simply impose a burden on the employee cannot be restrictive covenants. This is despite the fact that some disincentives, such as being required to compensate the former employer with a large sum of money, "operate as effectively at dissuading competitive conduct and participation in the marketplace as a prohibition."

The functionalist approach, on the other hand, asks whether "the clause at issue attempts to, or effectively does, restrain trade, in which case it will be captured by the doctrine and subjected to reasonableness scrutiny." "78 It goes beyond the structure of the clause to focus on the effect. Though the approach adopted will necessarily have implications as to whether the clause is deemed unenforceable or not, the law is not uniform in Canada as to whether the functionalist or formalist approach is preferred.

2007 ABQB 46, [2007] 5 WWR 300 at paras 4-10 [Community Credit].

Ibid at paras 47-48.

2009 CanLII 32268 at para 6 (Ont Sup Ct J).

Ibid.

Rhebergen, supra note 5 at para 28.

Ibid. 
Recently, in Rhebergen, the British Columbia Court of Appeal unequivocally stated its preference for the functionalist approach. ${ }^{79}$ Although this point arose in the dissenting reasons of Justice Lowry, the majority concurred with his analysis. ${ }^{80}$

Rhebergen involved an employee, Dr. Stephanie Rhebergen, and her employer, Creston Veterinary Clinic (CVC) ${ }^{81}$ To give some context, $\mathrm{CVC}$ is an isolated veterinary clinic which draws its customers from a handful of dairy farms located in the Creston, British Columbia area. Rhebergen entered into an associate agreement with $\mathrm{CVC}$, wherein she would work with CVC for three years. The associate agreement also had a clause which provided Rhebergen would be required to pay $\mathrm{CVC}$ if, within three years after the agreement was terminated, she set up practice in Creston or near CVC's place of business. The minimum amount Rhebergen would have to pay for engaging in the impugned conduct was $\$ 90,000$. A little over a year into the agreement, differences arose between Rhebergen and CVC and the agreement was terminated. Rhebergen then sought a declaration that the clause was unenforceable.

The trial judge gave brief reasons and found that the clause was in fact a non-competition clause, even though it did not directly prevent Rhebergen from competing with CVC. ${ }^{82} \mathrm{CVC}$ appealed, and one of the issues before the Court of Appeal was whether the clause constituted a restraint of trade. ${ }^{83}$

In his reasons for preferring the functionalist approach, Justice Lowry noted that the approach has been widely accepted in English law, where it is clear that a strict prohibition is not required for the doctrine of restraint of trade to apply. ${ }^{84}$ Justice Lowry acknowledged that the form of the clause should not be given precedence over the effect, stating:

In my view, the functionalist approach established in English law is to be preferred as the legal basis for determining whether clauses that burden employees with financial consequences, whether by payment or forfeiture, they would not otherwise have for engaging in post-employment competition constitute a restraint of trade. In the words of Lord Wilberforce, it is a matter of the effect of the clause in practice over its form. ${ }^{85}$

However, the courts in Ontario have generally preferred the formalist approach. In a much earlier decision, Inglis v. The Great West Life Assurance Co., the Ontario Court of Appeal held that a burden on the former employee did not constitute a restraint of trade. ${ }^{86}$ The burden in Inglis took the form of a forfeiture of future commission payments if the employee engaged in business competitive with the employer's business.

More recently, in Levinsky v. Toronto-Dominion Bank, the Ontario Superior Court of Justice considered a clause (the "Forfeiture Clause") in an employment agreement in which the former employee of a major bank was denied entitlement to restricted share units (the

Ibid at para 28-29, Lowry JA dissenting.

Ibid at para 71 .

Ibid at paras $2-8$.

Ibid at para 21.

Ibid at para 8.

Ibid at para 29.

Ibid at para 42.

(1941), [1942] 1 DLR 99 (Ont CA) [Inglis]. 
RSUs) ${ }^{87}$ The RSUs were granted by the bank as part of a long term compensation plan the employee would receive a specified number of RSUs each year, and after three years the RSUs would mature into cash. ${ }^{88}$ The Forfeiture Clause provided that the employee's entitlement to RSUs would be forfeited without notice if he resigned from his position prior to those RSUs maturing. The employee resigned from his position to start his own hedge fund. At the time the employee left his employment, he had RSUs valued at over \$1.6 million which had not yet matured.

In Levinsky, the Court undertook an extensive review of the authorities and seemed to acknowledge that a particular provision might be a restraint of trade even though it does not carry an explicit prohibition with it. ${ }^{89}$ However, the Court found that it was still bound by Inglis. ${ }^{90}$ Further, the Court commented that a clause which operates to forfeit compensation upon or following the cessation of an employment agreement requires looking at whether the forfeiture is linked only to the termination of the employment or whether it is linked to the employee engaging in competition with the former employer:

If the forfeiture results simply from the cessation of the employee's service, without more, the clause does not operate in restraint of trade because it does not fetter the employee's ability to choose where he or she wants to work next. Of course, a court must inquire into the circumstances under which the clause came into force to ensure that it was not the product of unfair dealing or bargaining. ${ }^{91}$

Since the operation of the Forfeiture Clause only depended on whether the employee resigned and not what he did post-employment, it was upheld and found not to be a restraint of trade. ${ }^{92}$

\section{Pre-Existing Employment Agreements}

\section{A. Fresh CONSIDERATION}

It is trite law that all contracts require the elements of offer, acceptance and a passing of consideration between the parties. Without these elements, the contract is neither binding nor enforceable. In the context of employment law, this entails that unilateral changes to an employment agreement may render it, and any restrictive covenants contained within it, unenforceable.

Generally speaking, restrictive covenants can be introduced into a pre-existing employment arrangement in two ways. The first is by having the employee enter into an employment agreement which includes the restrictive covenant (as part of one and the same contract) and the second is by having the employee sign a separate agreement for the restrictive covenant. In either scenario, if there is no fresh consideration given, the restrictive covenant will likely be unenforceable.

2013 ONSC 5657, 117 OR (3d) 106 [Levinsky].

Ibid at paras $1-3$.

Ibid at para 50 .

Ibid at para 80 .

Ibid at para 81 .

Ibid at paras 83-91. 
Further continued employment, in and of itself, is often insufficient consideration to enforce a restrictive covenant. The Ontario Superior Court explained the reason for this concisely in Kohler Canada Co. v. Porter, when the Court stated that "[c]ontinued employment, without anything more of value passing to an existing employee, is not consideration for a new promise disadvantageous to the employee." ${ }^{93}$

In Kohler, the employer did not ask the employee to enter into an employment agreement until several years after he had been employed. ${ }^{94}$ When he was finally asked to enter into an employment agreement, it included a restrictive covenant prohibiting the employee from working anywhere in North America in a competitive line of business, for a period of one year after termination of the employment relationship. The employee later resigned and went on to work with one of the employer's competitors. The employer applied for an injunction to prevent the employee from working for the competitor.

Not only did the Court find that the restrictive covenant failed the reasonableness test, but the Court also held that the agreement would be primarily unenforceable due to the absence of fresh consideration when the employment agreement was entered into:

\begin{abstract}
In the case before me, there was no consideration flowing to Mr. Porter in exchange for his promise to give up the right to work for any competitor of Kohler for a one year period post employment. The stated consideration of continued "employment status with Kohler and the payment of salary during such employment" are things that Mr. Porter was already entitled to under his existing employment relationship with Kohler. The non-competition clause was clearly an amendment to the existing employment relationship that was adverse to the employee. As such, the employer is required to give something of value to the employee in exchange for that promise, beyond continued employment to which the employee is already entitled under the original contract. Mr. Porter was significantly disadvantaged by the non-competition clause and he received nothing of value by way of additional consideration for signing it. I therefore find that the plaintiff has failed to discharge its onus of showing a strong prima facie case that there was consideration for the October 2001 employment agreement. Without consideration, the employment agreement is not enforceable and the plaintiffs are not entitled to the injunction sought. ${ }^{95}$
\end{abstract}

In Globex Foreign Exchange Corp. v. Kelcher, the Alberta Court of Appeal also held agreements imposing restrictive covenants on pre-existing employees unenforceable for want of consideration..$^{96}$ In that case, the three defendants were former employees of the plaintiff. Two of the employees were made to enter agreements containing restrictive covenants during their employment, but without any fresh consideration from the employer.

Again, the lack of fresh consideration rendered the restrictive covenants unenforceable. The majority of the Court confirmed that continued employment, without more, is not sufficient consideration for changes to the employment agreement that is adverse to the employee:

(2002), 26 BLR (3d) 24 at para 31 (Ont Sup Ct J) [Kohler].

Ibid at paras $2-9$.

Ibid at para 40 [citation omitted].

2011 ABCA 240, 337 DLR (4th) 207 [Globex Foreign Exchange]. 
Neither Kelcher nor Oliverio received anything beyond that to which they were already entitled when, during their employment, they accepted the restrictive covenants. The trial judge found, based on evidence, that there was no promise made or implied by the appellant that their employment would continue as a result of their signing. This Court has already interpreted Maguire in CA No 1 to require a tacit understanding which was not found in this case. If I had to decide the point, I would conclude that Kelcher and Oliverio were not bound by the restrictive covenants due to the lack of consideration. ${ }^{97}$

However, there are rare exceptions to the rule that fresh consideration is required. For example, in Levinsky, a secondary argument advanced by the former employee was that the Forfeiture Clause was introduced without fresh consideration. ${ }^{98}$ That is, at the time the Forfeiture Clause was introduced, he had already been entitled to participate in the long term compensation plan for a few years. Although he had signed new agreements acknowledging the Forfeiture Clause, the former employee had not been given any new consideration by the bank in exchange for the modification to the employment agreement. The former employee contended that the terms of the long term compensation plan were "imposed" on him. ${ }^{99}$

The Ontario Superior Court rejected this argument finding that the former employee was "at the time and has continued to be a well-educated, sophisticated businessman."100 Moreover, the Court found that the former employee had reaped substantial benefits under the long term compensation plan, without any complaint. ${ }^{101}$ Thus, in addition to the finding that the covenant could not be properly characterized as a restrictive covenant, it would not be unenforceable for lack of consideration.

Despite the Levinsky decision, the authorities largely confirm that introducing a restrictive covenant into an employment relationship, without giving the employee anything more, is a risky endeavour for the employer.

\section{B. WRONGFUL TERMINATION}

Globex Foreign Exchange also brought to the forefront the issue of whether restrictive covenants in an employment agreement are still enforceable when an employer wrongfully terminates the employee. ${ }^{102}$ Recall that there were three employees bound by the restrictive covenants imposed by the employer in Globex Foreign Exchange. The third employee was in a different scenario than the first two, in that he had entered into an employment agreement containing the restrictive covenant when his employment originally commenced. Then, when the employer later attempted to impose an even more burdensome restrictive covenant, the employee refused and was fired.

The majority in Globex Foreign Exchange conducted a detailed review of the line of authorities arising from the early English decision in General Billposting Co. Ltd. v. 
Atkinson, which stands for the principle that wrongful termination renders a restrictive covenant unenforceable. ${ }^{103}$ The majority, in following this principle, reasoned as follows:

$[T] \mathrm{o}$ hold otherwise would reward employers for mistreating their employees. For example, an employer could hire a potential competitor, impose a restrictive covenant on the employee, then wrongfully dismiss her a short time later and take advantage of the restrictive covenant.... A second justification (alluded to by Simon Brown L.J. in Rock Refrigeration) may be that enforcing a restrictive covenant in the face of wrongful termination prima facie negates the consideration (whether continued employment or something else) given by the employer to the employee when she accepted the restrictive covenant. Said another way, because the employment was prematurely and wrongfully terminated the employee will not "have received, during the period of his or her employment, an extra amount of remuneration for having conceded to be bound by the restraint in the contract": Employment Law in Canada at $\$ 11.48 .{ }^{104}$

The majority's reasoning in Globex Foreign Exchange implies that repudiation of an employment contract by an employer will cause a restrictive covenant to be unenforceable. Although the decision concerned itself with wrongful termination, in concluding that part of the analysis the majority emphasized that "[o]nce the appellant repudiated MacLean's contract by wrongfully dismissing him and he accepted that repudiation by taking another job, MacLean was not prospectively bound by the restrictive covenants."

An employer may also be found to repudiate an employment agreement where an employee is constructively dismissed. In contrast to the situation where employment is terminated outright, constructive dismissal occurs when the employer unilaterally alters the conditions of work in such a fundamental way that the law deems the employment to be at an end. ${ }^{106}$ Thus, a constructive dismissal, and corresponding repudiation, may occur even if the employer has no intention to terminate the employment relationship. For example, in Potter v. New Brunswick Legal Aid Services Commission, the Supreme Court of Canada held that an employee was constructively dismissed where he was suspended for administrative reasons without the employer giving any legitimate business reason to do so. ${ }^{107}$ This was held to be constructive dismissal despite the fact that the employee continued to be paid by the employer during the suspension. As a result, employers should be wary of rendering restrictive covenants unenforceable, whether it is through terminating employment outright or by making significant changes to the conditions of work.

\section{RECOMMENDATIONS}

As shown above, the law governing restrictive covenants in employment agreements has evolved rapidly in recent years and continues to do so. Considerable care should be taken when drafting or implementing restrictive covenants to ascertain that the clause used will withstand the generally unsympathetic treatment of Canadian courts if it is challenged. In that regard, there are a few points that should be kept in mind as best practices for drafting or utilizing restrictive covenants: 
Reasonableness: The utmost care should be taken to ensure that the clause is reasonable given the factual matrix of the employment relationship. The employer should clearly identify the proprietary interests that require protection so that the clause is not found to be overbroad. Further, the geographic and temporal scope as well as the range of business activities covered by the wording of the clause should be assessed carefully and critically prior to the implementation of the clause.

Ambiguity and Severance: Those drafting should keep in mind that the courts will not grant a restrictive covenant the same leeway in interpretation that a clause in commercial agreement may receive. Moreover, Canadian courts are restrained from utilizing severance to amend restrictive covenants. As such, there will effectively be no second chances for poorly drafted clauses.

Creative Clauses: The Court of Appeal in British Columbia has stated conclusively that the effect of a clause will be determinative in finding whether it is in restraint of trade. As a result, employers in British Columbia should reflect on what post-employment burdens are being imposed through their employment agreements, lest they be held unenforceable as restraints of trade. This is also an area of the law to keep abreast of, as courts will likely be giving more definitive answers following the Rhebergen decision as to whether the functionalist or formalist approach rules.

Pre-existing Employment Relationships: To avoid a challenge that a restrictive covenenant in an employment contract is unenforceable for want of consideration, it is preferable that the employer include it in the employment agreement at the start of the employment relationship. However, where this is not possible, the introduction of a restrictive covenant during the employment relationship should always be accompanied with fresh consideration to ensure that the agreement is enforceable.

Wrongful Dismissal: Employers should take precautions when dismissing employees to minimize the risk of wrongful dismissal. Wrongful dismissal amounts to repudiation of the employment contract by the employer. As per Globex Foreign Exchange, an employer who repudiates a contract will not be permitted to simultaneously rely on restrictive covenants contained in the same contract. ${ }^{108}$ This is particularly relevant for key employees where the employer may be relying significantly on restrictive covenants to protect against the employee's post-employment conduct.

In conclusion, the path to having an enforceable restrictive covenant is a tricky one and not void of obstacles. The courts in Canada have demonstrated that restrictive covenants will easily be struck down where they are unreasonable restraints of trade. So long as the courts remain unsympathetic towards restrictive covenants, one thing is clear: freedom of contract may prevail, but that will all depend on the skill of the drafter. 